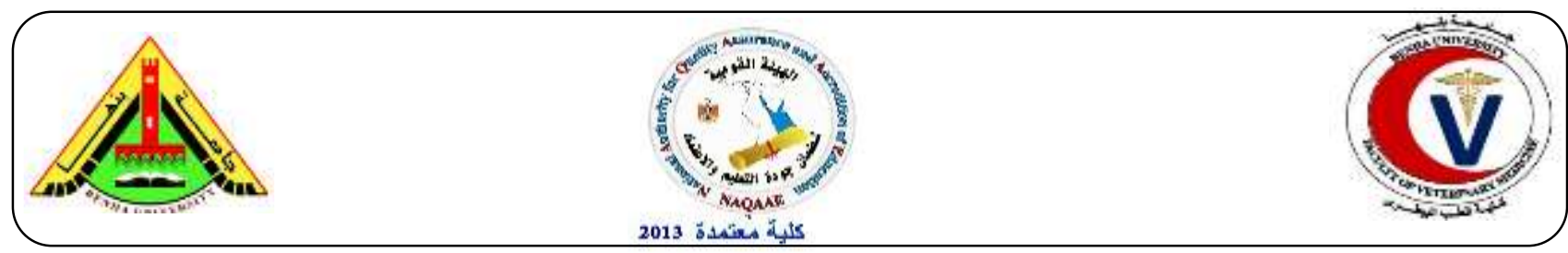

\title{
Determination of aflatoxins by HPLC and the identification of biosynthetic nor- 1 gene of aflatoxinsin poultry products by PCR assay
}

\author{
Ashraf A. Abd El-Tawab ${ }^{1}$, Fatma El-Hofy ${ }^{1}$, Ayman Mahmoud ${ }^{2}$, Dina Rashed ${ }^{3}$ \\ ${ }^{1}$ Department of Bacteriology, Faculty of Veterinary Medicine, Benha University \\ ${ }^{2}$ Department of Bacteriology, Animal Health Research Institute, Dokki, Giza, Egypt \\ ${ }^{3}$ Animal Health Research Institute, Zagazig, Egypt
}

\section{A B S T R A C T}

Aflatoxins residues in different poultry products were determined using HPLC technique and the expression of biosynthetic nor-1 gene of these aflatoxins by PCR assay. 90 different chicken products were analyzed for presence of aflatoxins (AFB1, AFB2, AFG1 and AFG2) using highly accurate, robust, selective, sensitive and precise HPLC-FLD assay. Incidence of aflatoxins in examined samples showed that the level of AFB1, AFB2 and AFG2 were $10 \%$ for each and of AFG1 was $16.7 \%$. The highest aflatoxins levels of analyzed samples were found in the liver. Expression of nor-1 gene of aflatoxins in polluted poultry products by PCR assay. A Real time PCR (RT-PCR) technique was applied to detect the gene expression of structural nor-1, which catalyzed the first step in the biosynthetic pathway of aflatoxins. The obtained results showed a very strong relationship between the presences of aflatoxins biosynthetic genes as analyzed by multiplex PCR and aflatoxins determination by HPLC/FLD.

Keywords: Aflatoxins; HPLC; norl gene; PCR.

Received: 13 June 2019, Accepted: 21 August 2019 (http://www.bvmj.bu.edu.eg) (BVMJ-36(2): 161-186, 2019)

\section{INTRODUCTION}

Mycotoxins are secondary metabolites produced by fungi such as A.flavus, A.parasiticus, A.ochraceous, F.tritinctum, F.poae and penicilliumspp.;aflatoxins, ochratoxins, patulin and T-2 are the most mycotoxins typescausing problems and associated with calamity outbreaks through the field (Hassan et al., 2015).

Aflatoxins attracted special attention by their ability to contaminate hundred kinds of poultry and poultry products such as chicken liver, nuggets, wings and thigh. These toxins production ability had been reported in different spp. of genus
Aspergillusfundamentally in section Flavigp. (Rodrigues et al., 2009).

Aflatoxins are produced by various spp. of Aspergillus, particularly A.parasiticus and A.flavus (Blesa et al., 2003; Kalcher et al., 2007 and $\mathrm{Yu}$ et al., 2008), about 60\% of isolates were aflatoxins producer (RazzaghiAbyaneh et al., 2006). The major aflatoxins are called aflatoxin B1, aflatoxin B2, aflatoxin G1 and aflatoxin G2 (AFB1, AFB2, AFG1 and AFG2) and their two metabolites AFM1 and AFM2, but AFB1 is the most toxigenic one. AFB1 and AFB2 are produced 
by A.flavus, while A.parasiticus produce the four aflatoxins (Dorner, 2004).

Aflatoxins are extremely toxic, highly mutagenic and carcinogenic compound, chemically. They are a group of di-fura-rocomarine derivative. The cause why gene expression of aflatoxins producer and nonproducer strains is obvious to be fundamental to follow the inculpated strains and its way in the environment. The most established assay for estimation of aflatoxins amounts in food and feed, is the HPLC technique depending on chemical and physical properties of mycotoxins provides anaccurate, precise and specific method to determine the aflatoxins concentrations in polluted food and feed. Many researches explain biological, analytical and genetic methods (Hassan et al., 2015).

Ochratoxin has four types (A, B, C and D) have been widely detected in food products. Ochratoxin A (OTA) is the most dangerous one. OTA is produced by A. spp., P.verrucosum and P.nordicum (Frisvad and Samson 2000; Larsen et al. 2001; Abarca et al., 2001 and Castella et al., 2002). Ochratoxin is immunosuppressive, teratogenic and carcinogenic effects; it is considering fertility inhibitor and mutagenic as it can pass placenta (IARC, 1993 and WHO, 2002). OTA has been considered as the major cause responsible for the "Balkan Endemic Nephropath" in humans (KuiperGoodman \& Scott, 1989).

The development of sensitive, accurate and rapid method for identification of incriminated aflatoxigenic species in foods and feed is main aim to avoid any potential health hazard and control mycotoxins (Valasek and Repa, 2005). Polymerase chain reaction (PCR) and real time Polymerase chain reaction (RT-PCR) have proved to be highly precise and rapid bimolecular techniques for genes expression or their transcripts participate in biosynthesis of mycotoxins by A.flavus and A.parasiticus (Fente et al. 2001; Somashekar et al., 2004 and Scherm et al., 2005).

The aim of the present study was to quantity Aflatoxins in 90 different poultry products by HPLC assay and to detect structural nor-1 gene expression by RT-PCR in contaminated samples. Nor-1 gene is a key structural gene in biosynthetic pathway of aflatoxins it encodes an enzyme that catalyze the conversion of the first stable aflatoxin biosynthesis intermediate norsolorininc acid to averantin.

\section{Materials and methods}

Materials:

Samples:

A grand total of 90 different chicken products (chicken wings, chicken nuggets, chicken liver and chicken thigh) "15 of each". The samples were collected from different supermarkets, Elsharqia. The samples were placed in plastic bags then transferredin an ice boxto the lab. without delay.

The collected samples were analyzed for the presence of aflatoxins (AFB1, AFB2, AFG1 and AFG2)

Material used for extraction of DNA:

QIAamp DNeasy Plant Mini kit Catalogue no.69104: DNeasy Plant Kits provide a fast and easy way to purify DNA from plant and fungal tissue. Up to $100 \mathrm{mg}$ of tissue can be processed using the DNeasy Plant Mini Kit. 
Ethanol 96\%: Applichem

PCR Master Mix used for conventional PCR:

Emerald Amp GT PCR mastermix (Takara)

Code No. RR310A Contains: (Emerald Amp GT PCR mastermix (2x premix) and PCR grade water).

Oligonucleotide primers used in conventional PCR:

They have specific sequence and amplify a specific product as shown in Table (1).

Table1: Percent of antibiotic residues positive beef samples.

\begin{tabular}{cccc}
\hline Gene & Sequence & $\begin{array}{c}\text { Amplified } \\
\text { product }\end{array}$ & Reference \\
& AAC CGC ATC & & \\
& CAC AAT CTC & & \\
aflR & AT & $800 \mathrm{bp}$ & Bintvihok, et \\
& AGT GCA GTT & & al., 2016 \\
& CGC TCA GAA & & \\
CA & & \\
\hline
\end{tabular}

DNA Molecular weight marker:

Gene ruler 100 bp DNA ladder (cat. no. SM0243) supplied from Fermentas.

Number of bands: 10

Size range: $100-1000 \mathrm{bp}$.

Material used for agarose gel electrophoresis:

Agarose 1.5\% (Sambrook et al., 1989): A multi-purpose, high gel strength agarose suitable for a wide range of molecular biology techniques. As it has high gel strength and exclusion limits, multi ABgarose could effectively separate large DNA fragments with reduced running times. This in turn means less band diffusion, a problem often associated with long running times. It was prepared as follow: (1.5 g Agarose powder (ABgene) and 100ml TBE.

Ethedium bromide solution $10 \mathrm{mg} / \mathrm{ml}$ (Sambrook et al., 1989): $10 \mathrm{mg}$ Ethedium bromide powder (Sigma) then add $1.0 \mathrm{ml}$ sterile DDW, mix and stored covered at $4^{\circ} \mathrm{C}$. It was added to melted agarose to reach a final concentration of $0.1-0.5 \mu \mathrm{g} / \mathrm{ml}$.

Tris borate EDTA (TBE) electrophoresis buffer (1x) (WHO, 2002): 10.78 gmofTris buffer, Fluka), 5.5 gm Boric acid, Fluka) and 0.82 gm EDTAdiNA, Winlab).It was completed up to 1 liter with DDW, $\mathrm{pH}$ was checked up. If the $\mathrm{pH}$ was out of the range of $8-8.6$, a new solution was prepared again. Any change in ion concentration would affect the DNA migration through the gel.

Methods:

Quantification of aflatoxins by HPLC:

Preparation of samples for residue study:

At the time of assay, partially thaw frozen tissues at room temperature (23oc) for 30 minutes and blend in a food processor for 20 30 seconds at high speed to obtain a uniform paste-like consistency.

Extraction and clean-up: (Brera et al., 2011):

1) Weight $5 \mathrm{gm}$ into a polypropylene tube.

2) Add $0.5 \mathrm{~g}$ of sodium chloride and $25 \mathrm{~mL}$ of methanol (80\%).

3) Mix at high speed for $3 \mathrm{~min}$. Filter the extract through filter paper.

4) Pipette $3 \mathrm{~mL}$ of filtrate and dilute with 3 $\mathrm{mL}$ of PBS. Mix thoroughly.

5) Centrifuge the diluted sample for $10 \mathrm{~min}$ at 10,000 rpm.

6) Apply $4 \mathrm{~mL}$ of the diluted sample to the conditioned immunoaffinity column (IAC) and wash with $1 \mathrm{~mL}$ of PBS. Elute mycotoxins in a 2-step procedure. First, apply $1.0 \mathrm{~mL}$ methanol to the IAC and let it flow through under gravity. Collect eluate in calibrated $5 \mathrm{~mL}$ volumetric flask. Wait 1 min and apply a second portion of $1.0 \mathrm{~mL}$ 
methanol. Pass air through the column to collect the remaining few drops.

7) Fill the $5 \mathrm{~mL}$ volumetric flask to the mark with DW, mix well, and store the sample at $+4 \circ \mathrm{C}$ prior to analysis.

Validation of analytical method:

The method was validated according to ICH, 2005 guidelines

Limit of Detection (LOD) and Quantification ( $L O Q)$ : They were calculated from Based on standard deviation of intercept (S) and slope (b) $\mathrm{LOD}=3.3 \times \mathrm{S} / \mathrm{b}$ and $\mathrm{LOQ}=10 \times \mathrm{S} / \mathrm{b}$

System Suitability Test: Relative standard deviations of the retention time, tailing factor, number of theoretical plates, peak area, and capacity factor were measured to test system suitability

Accuracy and recovery: The standard additions at different concentrations are prepared by adding known quantities of AFs \& OCA. Those samples are analyzed against standard solutions of same concentrations. The accuracy is then calculated from the test results as a percentage recovery.

Precision: It is determined using 5 replicates of each standard solutions and evaluating the relative standard deviation of repeatability (RSD \%).

Selectivity and specificity: Verification of selectivity is conducted by evaluating the standard addition on blank matrix. Acceptance criteria: there is no interference between the pure standard and peaks of any impurities or extracted solvents.

Irradiation effects on mycotoxins reduction: (Aziz et al., 2004):
Chicken product samples of high positive results were packed into polyethylene pouches and irradiated, in three replications, with doses of 6,8 and $10 \mathrm{KGy}$ by using $60 \mathrm{CO}$ gamma rays (Gamma Cell mold 220 apparatus, NCRRT, Nasr City, Cairo, Egypt). Expression of nor-1 gene of aflatoxins and ocrA gene of ochratoxin in polluted poultry products by a real time PCR (RT-PCR) technique:

Extraction of DNA (QIAamp DNeasy Plant Mini kitinstructions):

1) Freeze $100 \mathrm{mg}$ of the fungal tissue at $80^{\circ} \mathrm{C} / 24 \mathrm{hrs}$ for later processing.

2) Add fungal material and a tungsten carbide bead to a $2 \mathrm{ml}$ safe-lock tube. 400 $\mu 1$ Buffer AP1 and $4 \mu \mathrm{l}$ RNase A stock solution $(100 \mathrm{mg} / \mathrm{ml})$ were added. Tubes were placed into the adaptor sets, which are fixed into the clamps of the TissueLyser. Disruption was performed in two 1-2 min. at high-speed $(20-30 \mathrm{~Hz})$ shaking steps.

3) The mixture was incubated for at $65^{\circ} \mathrm{C} / 10$ min and mixed 2 or 3 times during incubation byinverting tube.

4) Add $130 \mu 1$ Buffer P3 to the lysate, mixed, and incubated for $5 \mathrm{~min}$ on ice.

5) The lysate was centrifuged for $5 \mathrm{~min}$ at $14,000 \mathrm{rpm}$.

6) The lysate was pipetted into the QIAshredder Mini spin column (lilac) placed in a $2 \mathrm{ml}$ collection tube, and centrifuged for $2 \mathrm{~min}$ at 14,000 rpm.

7) The flow-through fraction from step 16 was transferred into a new tube without disturbing the cell-debris pellet.

8) Add 1.5 volumes of Buffer AW1 to the cleared lysate, and mixed by pipetting. 
9) Pipette $650 \mu 1$ of the mixture from step 8 (including any precipitate that was formed) into the DNeasy Mini spin column placed in a $2 \mathrm{ml}$ collection tube and centrifuged for $1 \mathrm{~min} 8000 \mathrm{rpm}$ and the flow-through was discarded.

10) Step 9 was repeated with the remaining sample. The flow-through and collection tube were discarded.

11) The DNeasy Mini spin column was placed into a new $2 \mathrm{ml}$ collection tube.

12) Add $500 \mu$ Buffer AW2 was added to the DNeasy Mini spin column, and centrifuged for $2 \mathrm{~min}$ at $14,000 \mathrm{rpm}$ to dry the membrane.

13) The DNeasy Mini spin column was transferred to a $1.5 \mathrm{ml}$ or $2 \mathrm{ml}$ microcentrifuge tube, and $50 \mu \mathrm{l}$ Buffer AE were directly pipette onto the DNeasy membrane. It was incubated for $5 \mathrm{~min}$ at room temperature $\left(15-25^{\circ} \mathrm{C}\right)$, and then centrifuged for $1 \mathrm{~min}$ at $8000 \mathrm{rpm}$ to elute.

14) Step 13 was repeated once.

Preparation of conventional PCR MasterMix: (According to Emerald Amp GT PCR mastermix (Takara) Code No. RR310A kit as shown in table (2).

Table2: Components of PCR mastermix.

\begin{tabular}{cc}
\hline Component & Volume/reaction \\
\hline Emerald Amp GT PCR & $12.5 \mu l$ \\
mastermix (2x premix) & $4.5 \mu l$ \\
PCR grade water & $1 \mu l$ \\
Forward primer (20 pmol) & $1 \mu l$ \\
Reverse primer (20 pmol) & $6 \mu l$ \\
Template DNA &
\end{tabular}

Cycling conditions of the primers during cPCR:

Temperature and time conditions of the two primers during PCR are shown in Table (3).
Table3: Cycling conditions of the different primersduring conventional PCR.

\begin{tabular}{cccccc}
\hline $\begin{array}{c}\text { Primary } \\
\text { denaturati } \\
\text { on }\end{array}$ & $\begin{array}{c}\text { Secondary } \\
\text { denaturati } \\
\text { on }\end{array}$ & $\begin{array}{c}\text { Anneali } \\
\text { ng }\end{array}$ & $\begin{array}{c}\text { Extensi } \\
\text { on }\end{array}$ & $\begin{array}{c}\text { No. } \\
\text { of } \\
\text { cycle } \\
\mathrm{s}\end{array}$ & $\begin{array}{c}\text { Final } \\
\text { extensi } \\
\text { on }\end{array}$ \\
\hline $95^{\circ} \mathrm{C}$ & $94^{\circ} \mathrm{C}$ & $50^{\circ} \mathrm{C}$ & $72^{\circ} \mathrm{C}$ & & $72^{\circ} \mathrm{C}$ \\
5 min. & $30 \mathrm{sec}$. & $\begin{array}{c}1.25 \\
\text { min. }\end{array}$ & $\begin{array}{l}1.40 \\
\text { min. }\end{array}$ & 35 & $10 \mathrm{~min}$. \\
\hline
\end{tabular}

DNA Molecular weight marker:

The ladder was mixed gently by pipetting up and down. $6 \mu \mathrm{l}$ of the required ladder were directly loaded.

Agarose gel electrophoreses (Sambrook et al., 1989) with little modification:

Electrophoresis grade agarose $(1.5 \mathrm{~g})$ was prepared in $100 \mathrm{ml}$ TBE buffer in a sterile flask, it was heated in microwave to dissolve all granules with agitation, and allowed to cool at $70^{\circ} \mathrm{C}$, then $0.5 \mu \mathrm{g} / \mathrm{ml}$ ethedium bromide was added and mixed thoroughly.

The warm agarose was poured directly in gel casting apparatus with desired comb in apposition and left at room temperature for polymerization.

The comb was then removed, and the electrophoresis tank was filled with TBE buffer. Twenty $\mu \mathrm{l}$ of each PCR product samples, negative control and positive control were loaded to the gel. The power supply was $1-5$ volts/cm of the tank length. The run was stopped after about $30 \mathrm{~min}$ and the gel was transferred to UV cabinet.

The gel was photographed by a gel documentation system and the data was analyzed through computer software.

\section{RESULTS}

Quantification of aflatoxins by HPLC:

Intra-lab validation: 
The results of mycotoxins assay validation were illustrated in table (1), showing that the used method with high accuracy and extremely precise method as the Intra-day precision (RSD \%) not exceed $1.81 \%(<2 \%$ that recommended by USP, 2017) and the inter-day precision not exceed $2.63 \%(<6 \%$ that recommended by ICH, 2005).

There were high resolution of chromatograms, it is showed in the results as the retention time of Afla-G2, -G1, -B2, -B1 and OTA standards at $0.803,1.002,1.901$, 2.713 and $7.803 \mathrm{~min}$ (fig. 1).

Selectivity and specificity: As shown in fig (1\& 2), HPLC Chromatograms of mycotoxins pure standards and spiked matrix at different levels, showing no matrix interferences were observed on the chromatograms and no interfering peaks were obtained with the same retention times (RT) of mycotoxins peaks.

Mycotoxins residues in different chicken products:

Due to the toxicity and carcinogenicity impact of mycotoxins residues on human public health; our study includes detecting the residues on mycotoxins (Aflatoxins types; B1, B2, G1, G 2) and Ocratoxin A (OTA) in different chicken products samples

The data represented in table (2) showing Incidence of mycotoxins in different chicken products samples showed that the level of Afla B1, Afla B2 and Afla G2 were $10 \%$ for each and of Afla G1 and Ochra A were ranged from 10 to $16.7 \%$ for each.
Mycotoxins residues in different chicken products after exposure to gamma irradiation:

In all analyzed samples, there are a positive correlation between the increase of gamma irradiation dose applied to the samples and the level of reduction of total mycotoxins present in these samples. It is clear in table (9).

Expression of the structure genes (nor-1) of aflatoxins by RT-PCR:

The results showed that the DNA extract of the isolates A.flavus and A.parasiticus have the nor-1 gene in analyzed samples. Represented electrophoresis band pattern of Real time PCR products shown in (Fig 5).The RT-PCR results obtained with genomic DNAas a template indicated that all tested aflatoxigenic isolates expressed nor-1 gene with significant expression levels in chicken products. Positive correlation was noted between mean expression level of nor-1 and the amount of Aflatoxins production by isolates.

The observed differences in aflatoxins producing ability (Table 4) could be explained by differences in expression of aflatoxins biosynthetic and regulatory genes between toxigenic isolates from chicken productsdue to distinction in environmental circumstances. Transcriptional expression of the key aflatoxins biosynthetic gene nor-1 gene which encoding an enzyme catalyze the conversion of the first stable aflatoxins biosynthesis intermediate norsolorininc acid to averatin. Nor-1 gene was investigated by Real time PCR and as shown in (fig. 5) have expressed the nor-1 gene in different levels. 
Table 4: Validation sheet of mycotoxins.

\begin{tabular}{|c|c|c|c|c|c|}
\hline OTA & AFG2 & AFG1 & AFB2 & AFB1 & Parameter \\
\hline 7.803 & 0.803 & 1.002 & 1.901 & 2.713 & $\begin{array}{l}\text { Retention time } \\
\quad \text { (min.) }\end{array}$ \\
\hline \multicolumn{5}{|c|}{$0.015-0.3$} & Range (ppb) \\
\hline 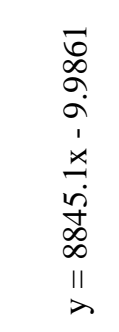 & 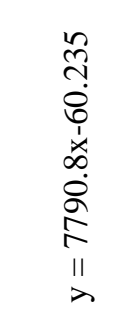 & 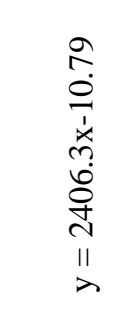 & 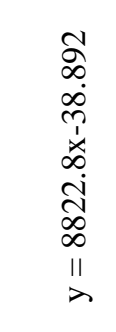 & 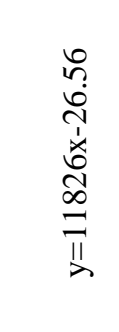 & 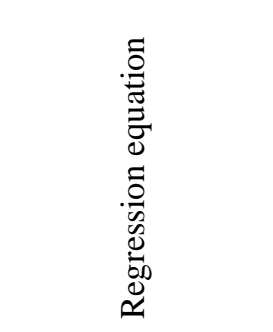 \\
\hline 0.9999 & 0.9995 & 0.9954 & 0.9961 & 0.9985 & $\begin{array}{c}\text { Correlation } \\
\text { coefficient }\left(\mathrm{R}^{2}\right)\end{array}$ \\
\hline 8845.1 & 7710.7 & 2406.3 & 8822.8 & 11826 & Slope (a) \\
\hline 9.9861 & 60.235 & 10.788 & 38.892 & 26.555 & Intercept (b) \\
\hline 0.008 & 0.014 & 0.015 & 0.014 & 0.002 & LOD \\
\hline 0.022 & 0.043 & 0.045 & 0.041 & 0.005 & LOQ \\
\hline $\begin{array}{l}= \\
\overrightarrow{0} \\
+1 \\
\overrightarrow{0} \\
8\end{array}$ & 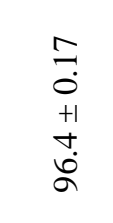 & \begin{tabular}{l}
\multirow{\jmath}{*}{} \\
$\dot{0}$ \\
+1 \\
$\infty$ \\
$\infty$ \\
$\infty$
\end{tabular} & $\begin{array}{l}0 \\
0 \\
+1 \\
\infty \\
\dot{\sigma}\end{array}$ & $\begin{array}{l}\bar{\sigma} \\
\dot{0} \\
+1 \\
\hat{\sigma} \\
\dot{\sigma}\end{array}$ & 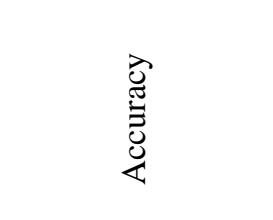 \\
\hline 100.07 & 101.82 & 95.9 & 92.2 & 98.7 & Recovery \% \\
\hline 0.046 & 1.81 & 0.23 & 0.45 & 0.07 & $\begin{array}{c}\text { Intra-day precision } \\
(\mathrm{RSD} \%)\end{array}$ \\
\hline 0.23 & 2.63 & 0.73 & 1.63 & 0.34 & $\begin{array}{c}\text { Inter-day precision } \\
(\mathrm{RSD} \%)\end{array}$ \\
\hline
\end{tabular}

Table 5: Results of mycotoxins residues in positive chicken products samples $n=30$.

\begin{tabular}{|c|c|c|c|}
\hline Mycotoxin & Type of sample & Positive samples & Mean \pm SE $(\mu \mathrm{g} / \mathrm{kg})$ \\
\hline & Nuggets & 3 & $5.03 \pm 0.65$ \\
\hline \multirow[t]{2}{*}{ Afla B1 } & Liver & 3 & $16.3 \pm 0.85$ \\
\hline & Thigh & 3 & $4.95 \pm 0.84$ \\
\hline \multirow{4}{*}{ Afla B2 } & Nuggets & 3 & $1.2 \pm 0.34$ \\
\hline & Liver & 3 & $10.1 \pm 0.99$ \\
\hline & Thigh & 3 & $0.84 \pm 0.11$ \\
\hline & Nuggets & 5 & $0.28 \pm 0.04$ \\
\hline \multirow[t]{2}{*}{ Afla G1 } & Liver & 3 & $1.58 \pm 0.24$ \\
\hline & Thigh & 3 & $0.24 \pm 0.05$ \\
\hline \multirow{3}{*}{ Afla G2 } & Nuggets & 3 & $0.06 \pm 0.01$ \\
\hline & Liver & 3 & $0.56 \pm 0.09$ \\
\hline & Thigh & ND & ND \\
\hline
\end{tabular}

ND: not detected

$\operatorname{LOD}(\mathrm{AFG} 2)=0.014 \mathrm{ppb}$ 
Table 6: Incidence of mycotoxins residues in chicken products samples.

\begin{tabular}{|c|c|c|c|c|}
\hline Percentage $(\%)$ & Positive samples & Samples no. & Type of sample & Mycotoxin \\
\hline 0 & - & 30 & Chicken wings & \multirow{5}{*}{ Afla B1 } \\
\hline 10 & 3 & 30 & Chicken nuggets & \\
\hline 10 & 3 & 30 & Chicken liver & \\
\hline 10 & 3 & 30 & Chicken thigh & \\
\hline 0 & - & 30 & Chicken wings & \\
\hline 10 & 3 & 30 & Chicken nuggets & \multirow{3}{*}{ Afla B2 } \\
\hline 10 & 3 & 30 & Chicken liver & \\
\hline 10 & 3 & 30 & Chicken thigh & \\
\hline 0 & - & 30 & Chicken wings & \multirow{5}{*}{ Afla G1 } \\
\hline 16.7 & 5 & 30 & Chicken nuggets & \\
\hline 10 & 3 & 30 & Chicken liver & \\
\hline 10 & 3 & 30 & Chicken thigh & \\
\hline 0 & - & 30 & Chicken wings & \\
\hline 10 & 3 & 30 & Chicken nuggets & \multirow{4}{*}{ Afla G2 } \\
\hline 10 & 3 & 30 & Chicken liver & \\
\hline 0 & - & 30 & Chicken thigh & \\
\hline 0 & - & 30 & Chicken wings & \\
\hline 10 & 3 & 30 & Chicken nuggets & \multirow{3}{*}{ Ochra A } \\
\hline 16.7 & 5 & 30 & Chicken liver & \\
\hline 10 & 3 & 30 & Chicken thigh & \\
\hline
\end{tabular}

Table 7: Results of mycotoxins residues in positive chicken products samples.

\begin{tabular}{|c|c|c|c|c|c|}
\hline \multicolumn{2}{|c|}{$\begin{array}{l}\text { Range } \\
(\mu \mathrm{g} / \mathrm{kg})\end{array}$} & \multirow{3}{*}{$\begin{array}{c}\text { Mean } \pm \mathrm{SE} \\
(\mu \mathrm{g} / \mathrm{kg}) \\
\mathrm{ND}\end{array}$} & \multirow{3}{*}{$\begin{array}{c}\text { No. of }+\mathrm{ve} \\
\text { samples } \\
\text { ND }\end{array}$} & \multirow{3}{*}{$\begin{array}{l}\text { Type of sample } \\
\text { Chicken wings }\end{array}$} & \multirow[t]{3}{*}{$\begin{array}{l}\text { Type of } \\
\text { sample }\end{array}$} \\
\hline Max. & Min. & & & & \\
\hline ND & ND & & & & \\
\hline 6.19 & 3.96 & $5.03 \pm 0.65$ & 3 & Chicken nuggets & \multirow{3}{*}{ Afla B1 } \\
\hline 17.9 & 15 & $16.3 \pm 0.85$ & 3 & Chicken liver & \\
\hline 6.63 & 4.1 & $4.95 \pm 0.84$ & 3 & Chicken thigh & \\
\hline ND & ND & ND & ND & Chicken wings & \multirow{5}{*}{ Afla B2 } \\
\hline 1.87 & 0.8 & $1.2 \pm 0.34$ & 3 & Chicken nuggets & \\
\hline 11.8 & 8.4 & $10.1 \pm 0.99$ & 3 & Chicken liver & \\
\hline 1.06 & 0.68 & $0.84 \pm 0.11$ & 3 & Chicken thigh & \\
\hline ND & ND & ND & ND & Chicken wings & \\
\hline 0.4 & 0.16 & $0.28 \pm 0.04$ & 5 & Chicken nuggets & \multirow{2}{*}{ Afla G1 } \\
\hline 2.02 & 1.21 & $1.58 \pm 0.24$ & 3 & Chicken liver & \\
\hline
\end{tabular}




\begin{tabular}{cccccc}
\hline 0.33 & 0.18 & $0.24 \pm 0.05$ & 3 & Chicken thigh & \\
ND & ND & ND & ND & Chicken wings & \\
0.08 & 0.05 & $0.06 \pm 0.01$ & 3 & Chicken nuggets & Afla G2 \\
0.73 & 0.41 & $0.56 \pm 0.09$ & 3 & Chicken liver & \\
ND & ND & ND & ND & Chicken thigh & \\
ND & ND & ND & ND & Chicken wings & \\
0.98 & 0.69 & $0.86 \pm 0.09$ & 3 & Chicken nuggets & Ochra A \\
1.6 & 0.9 & $1.15 \pm 0.12$ & 5 & Chicken liver & \\
0.62 & 0.39 & $0.5 \pm 0.07$ & 3 & Chicken thigh & \\
\hline
\end{tabular}

Table 8: Distribution of mycotoxins in different chicken products.

\begin{tabular}{cccc}
\hline Thigh & Nuggets & Liver & Mycotoxins \\
\hline $1.63^{\mathrm{a}}$ & $1.34^{\mathrm{a}}$ & 5.37 & Mean \\
0.61 & 0.45 & 1.53 & SE
\end{tabular}

Table 9: Results of mycotoxins in different chicken products after exposure to gamma irradiation.

\begin{tabular}{|c|c|c|c|c|c|}
\hline & rradiation dose ( $\mathrm{k}$ & & (Control & & \\
\hline & ppb (Reduction ? & & & Sample type & \\
\hline 10 & 8 & 6 & & & \\
\hline & & & & Chicken & \\
\hline $4.1(33.7 \%)$ & $4.97(19.7 \%)$ & $5.97(3.6 \%)$ & 6.19 & & \\
\hline & & & & nuggets & \\
\hline $13.4(25 \%)$ & $14.74(17.5 \%)$ & $16.8(6 \%)$ & 17.87 & Chicken liver & AFB 1 \\
\hline $0.46(26.6 \%)$ & $0.51(16.5 \%)$ & $0.57(7.5 \%)$ & 0.62 & Chicken thigh & \\
\hline 1.13 & & & & Chicken & \\
\hline$(39.6 \%)$ & $1.3(20 \%)$ & $1.74(6.8 \%)$ & 1.87 & nuggets & \\
\hline 7.14 & & & & & \\
\hline$(39.5 \%)$ & $9.12(22 \%)$ & $11.5(6 \%)$ & 11.8 & Chicken liver & AFB2 \\
\hline 0.55 & & & & & \\
\hline$(48.4 \%)$ & $0.83(22 \%)$ & $0.95(10 \%)$ & 1.06 & Chicken thigh & \\
\hline & & & & Chicken & \\
\hline $0.18(55 \%)$ & $0.24(40 \%)$ & $0.34(15 \%)$ & 0.4 & nuggets & \\
\hline $0.81(60 \%)$ & $1.41(30 \%)$ & $1.72(15 \%)$ & 2.02 & Chicken liver & \\
\hline
\end{tabular}




\begin{tabular}{|c|c|c|c|c|c|}
\hline & & 0.28 & & & AFG1 \\
\hline \multirow[t]{3}{*}{$0.03(90 \%)$} & $0.14(42.2 \%)$ & & 0.33 & Chicken thigh & \\
\hline & & $(15.2 \%)$ & & & \\
\hline & 0.043 & 0.07 & & Chicken & \\
\hline \multirow[t]{2}{*}{$0.01(86 \%)$} & & & 0.08 & & \\
\hline & $(46.2 \%)$ & $(15.4 \%)$ & & nuggets & \\
\hline \multirow[t]{2}{*}{0.06} & & & & & AFG2 \\
\hline & $0.4(45 \%)$ & $0.64(12 \%)$ & 0.73 & Chicken liver & \\
\hline \multicolumn{6}{|l|}{$(91.4 \%)$} \\
\hline \multirow[t]{2}{*}{0.04} & & & & Chicken & \\
\hline & $0.59(40 \%)$ & $0.74(25 \%)$ & 0.98 & & \\
\hline$(96.4 \%)$ & & & & nuggets & \\
\hline $0.64(60 \%)$ & $0.88(45 \%)$ & $1.2(25 \%)$ & 1.6 & Chicken liver & \\
\hline \multirow[t]{2}{*}{0.155} & & & & & OTA \\
\hline & $0.25(60 \%)$ & $0.5(20 \%)$ & 0.62 & Chicken thigh & \\
\hline$(75 \%)$ & & & & & \\
\hline
\end{tabular}

Table 10: Total mycotoxins after gamma irradiation exposure.

\begin{tabular}{|c|c|c|c|c|}
\hline \multicolumn{3}{|c|}{ Irradiation dose (kGy) } & \multirow{2}{*}{$\begin{array}{c}\text { (Control) } \\
\text { conc. } \mathrm{ppb} \pm \mathrm{SE}\end{array}$} & \multirow{2}{*}{$\begin{array}{c}\text { Mycotoxin } \\
\text { type }\end{array}$} \\
\hline 10 & 8 & 6 & & \\
\hline $\begin{array}{c}5.99 \pm 3.85 \\
(27.22 \%)\end{array}$ & $\begin{array}{c}6.74 \pm 4.2 \\
(18.1 \%)\end{array}$ & $\begin{array}{c}7.78 \pm 4.77 \\
(5.47 \%)\end{array}$ & $8.23 \pm 5.08$ & AF B1 \\
\hline $\begin{array}{c}2.94 \pm 2.11 \\
(40.12 \%)\end{array}$ & $\begin{array}{c}3.75 \pm 2.69 \\
(23.63 \%)\end{array}$ & $\begin{array}{c}4.73 \pm 3.92 \\
(3.6 \%)\end{array}$ & $4.91 \pm 3.45$ & AF B2 \\
\hline $\begin{array}{c}0.34 \pm 0.24 \\
(63.04 \%)\end{array}$ & $\begin{array}{l}0.6 \pm 0.4 \\
(34.78 \%)\end{array}$ & $\begin{array}{c}0.78 \pm 0.47 \\
(15.22 \%)\end{array}$ & $0.92 \pm 0.55$ & AF G1 \\
\hline $\begin{array}{c}0.04 \pm 0.02 \\
(90.24 \%)\end{array}$ & $\begin{array}{c}0.22 \pm 0.18 \\
(46.34 \%)\end{array}$ & $\begin{array}{c}0.36 \pm 0.29 \\
(12.2 \%)\end{array}$ & $0.41 \pm 0.32$ & AF G2 \\
\hline $\begin{array}{c}0.28 \pm 0.2^{\mathrm{a}} \\
(73.83 \%)\end{array}$ & $\begin{array}{c}0.57 \pm 0.18 \\
(46.73 \%)\end{array}$ & $\begin{array}{c}0.81 \pm 0.2 \\
(24.3 \%)\end{array}$ & $1.07 \pm 0.29$ & OTA \\
\hline $\begin{array}{c}2.05 \pm 1.07 \\
(37.88 \%)\end{array}$ & $\begin{array}{c}2.53 \pm 1.21 \\
(23.33 \%)\end{array}$ & $\begin{array}{c}3.07 \pm 1.4 \\
(6.97 \%)\end{array}$ & $3.3 \pm 1.5$ & $\begin{array}{c}\text { Total } \\
\text { mycotoxins }\end{array}$ \\
\hline
\end{tabular}




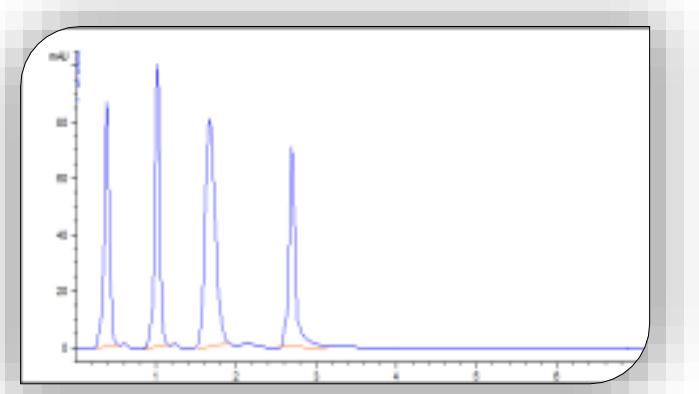

Fig.1. Chromatogram of AF- G2, -G1, -B2 and-B1 standards at a conc. of $(0.03,0.075,0.02$ and 0.015 ppb; respectively).

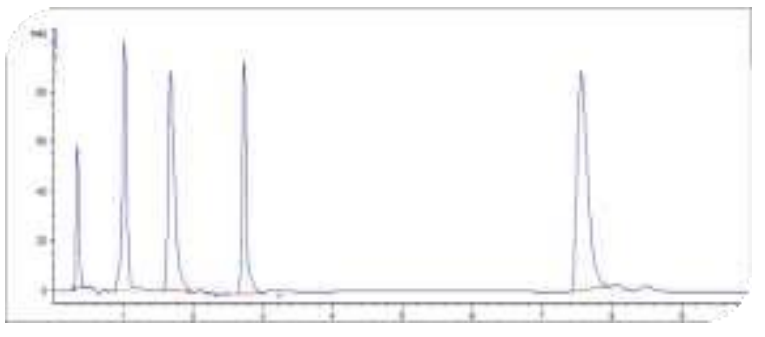

Fig.2. Chromatogram showing Afla-G2, -G1, -B2, -B1 and OTA spiked matrix at a conc. of $(0.015,0.06,0.03,0.03$ and $0.02 \mathrm{ppb}$; respectively).

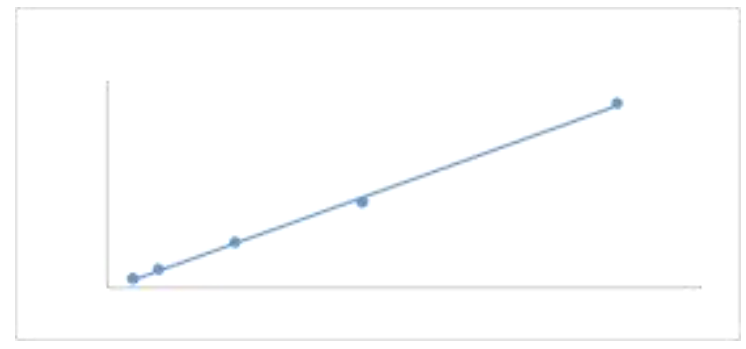

Fig.3. Standard curve of AFB1.

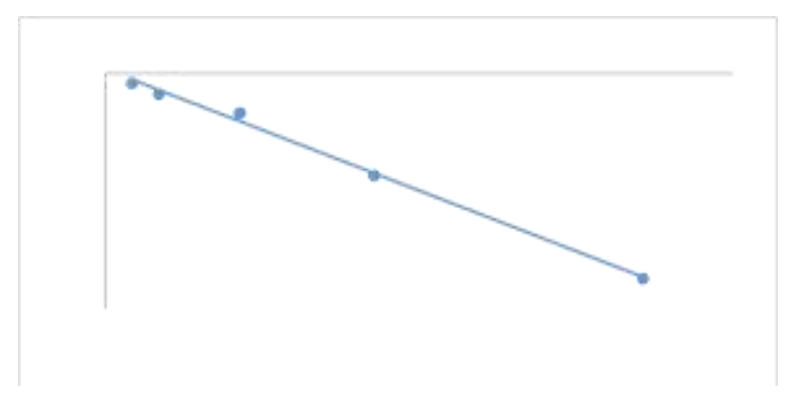

Fig.4. Standard curve of AFB2. 


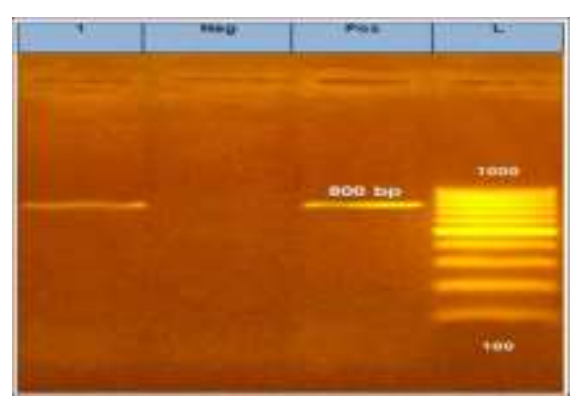

Fig.5. Agarose gel electrophoresis of nor-1 gene expression, PCR amplification product at 800 bp.

\section{DISCUSSION}

Mycotoxins residues in different chicken products:

Incidence of mycotoxins in different chicken products samples showed that the level of aflatoxin B1, aflatoxin B2 and aflatoxin G2 were $10 \%$ for each and of aflatoxin G1 and ochratoxin A were ranged from 10 to $16.7 \%$.

Our study showing that the highest mycotoxins residues (sum. of AFB1, AFB2, $\mathrm{AFG} 1, \mathrm{AFG} 2$ and OTA) were found in chicken liver (5.37 $\pm 1.53 ; 64 \%)$, followed by chicken thigh $(1.63 \pm 0.61 ; 20 \%)$ and chicken nuggets $(1.34 \pm 0.45 ; 16 \%)$ and finally chicken wings (not detected). Ochratoxin A residue was found in chicken liver (1.15 \pm $0.12)$ higher than chicken nuggets $(0.86 \pm$ $0.09)$ followed by thigh samples $(0.5 \pm 0.07)$. The results refer to that the highest concentration of examined mycotoxins were present in liver as the liver is the harbor site of mycotoxins residues. These finding agree with of those obtained by (Dragan et al., 2011) in Serbia who recorded that the incidence of OTA in chicken liver, kidney and gizzard samples from chicken was $38.33 \%, 28.3 \%$ and $26.6 \%$, respectively, with levels ranging from 0.14 to $3.9 \mathrm{ng} / \mathrm{g}$ in liver, 0.1 to $7.02 \mathrm{ng} / \mathrm{g}$ in kidneys and 0.25 to 9.94 $\mathrm{ng} / \mathrm{g}$ in gizzard. In Czech Repulic, reported that ochratoxin residues was $0.12 \mathrm{ppb}$ in chicken meat.Liver is the primary organ involved in mycotoxin detoxification, which is probably the reason why it was affected much more than the kidneys (Yang et al., 2013)

Our data are agree with those reported with Hassanin et al., 2016. They found that chicken burger $(1.63 \mathrm{ppb})$, followed by chicken nuggets (1.04 ppb), luncheon (0.98 $\mathrm{ppb})$ and frankfurter $(0.82 \mathrm{ppb})$, chicken thigh $(0.68 \mathrm{ppb})$, pannet $(0.43 \mathrm{ppb})$ and finally chicken wings $(0.29 \mathrm{ppb})$. While the incidence is so lower than that reported in Egypt by Nahed et al., 2016 who reported that incidence of ochratoxin in chicken burger and luncheon was $70 \%$ and $80 \%$, respectively. The residue of ochratoxin was very low in their study, where OTA residues were 0.277 and $0.243 \mathrm{ppb}$ in chicken burger and luncheon, respectively. This could be explained by the fact that in our work we used HPLC-FLD which consider highly precise and accurate technique for determination of mycotoxins residues.

The obtained results were agreed with those achieved by Resanović, 2000 and Saeed et al., 2003 who declared that however aflatoxins residues found in liver, muscles, stomach, kidneys, adipose tissue and meat but liver is 
the harbor site of aflatoxin residues. In the same line the results agreed with those obtained by Bennett and Klich, 2003, Miliţăet al., 2010, Herzallah, 2013, Hasanen et al., 2016 and Darwish et al., 2016 who reported that the highest concentration of AFB1 and total aflatoxins were in liver higher than in kidneys than in gizzard, while the lowest concentrations were in thigh and breast. The present results are completely disagreed with those achieved by Abo El-Yazeedetal., 2015 who detected that the residual concentrations were higher in breast than in liver.

Markov et al., 2013 from Croatia reported that mycotoxins were detected in $64 \%$ of 90 meat samples analyzed, and found that $10 \%$ of the samples were contaminated with AFB1, with a maximum AFB1 level of $3.0 \mathrm{mg} / \mathrm{kg}$. Using different testing systems, Herzallah, 2009 found levels of total aflatoxins in imported and fresh meat samples collected during March ranged from 0.15 to $6.36 \mu \mathrm{g} / \mathrm{kg}$. In a review study, Rodriguez-Amaya and Sabino, 2002 from Brazil found variable frequency of AFB1 contamination in chicken liver samples; with positivity at $\sim 50 \%$ of samples tested, and maximum mean level 3.2 $\mu \mathrm{g} / \mathrm{kg}$.

Bintvihok et al., 2002 found that aflatoxin B1 and its metabolite residues were detected in liver $(0.15 \mathrm{ppb})$, muscle (not detected) of domestic fowls after fed them with aflatoxin B1 (3 ppm) for seven days, samples were purified with a Sep-Pak florosil and quantified by HPLC.

Arulmozhi et al. 2002 reported that broiler chicks exposed to aflatoxin (100 ppb) for six weeks, aflatoxin residues detected on $45^{\text {th }}$ day in liver, kidney and muscle by HPLC ( 6.6, 3.2 and $5.1 \mathrm{ng} / \mathrm{g}$ respectively)

Broiler chicks of 7, 14 and 28 days of age exposed to different dietary levels of AFB1 (1600, 3200 and $6400 \mu \mathrm{g} / \mathrm{kg}$ ) for 7 days. Maximum AFB1 residue (6.97 and $3.27 \mathrm{ng} / \mathrm{g}$ in liver and muscle respectively) concentration was high in young age birds those kept on high AFB1 ration. After withdrawal of $\mathrm{AF}$ contaminated rations, residues clearance was slow and AFB1 was detectable in liver and muscles of birds for longer duration in younger birds fed with high AFB1 dietary levels (Zahid et al., 2010)

Yang et al., 2012 conducted an experiment where broilers fed daily with corn naturally contaminated with AFB1 and AFB2 (134 and $23.6 \mu \mathrm{g} / \mathrm{kg}$ respectively) and aflatoxins extracted by AflaStar ${ }^{\mathrm{TM}} \mathrm{R}$ immunoaffinity columns and determined by HPLCMS/MS technique. AFB1 residues in livers and breast muscles were at levels of 0.137 and 0.016 $\mu \mathrm{g} / \mathrm{kg}$, respectively.

Fan et al., 2013 conducted an experiment where broilers were fed with a moldy peanut meal naturally contaminated with aflatoxins (AFB1 $330 \mu \mathrm{g} / \mathrm{kg}$ ) for 42 days and aflatoxin residues in liver and muscle samples were detected by HPLC-FD with postcolumn photochemical derivation as samples subjected to immunoaffinity columns, where AFB1 in liver was $0.24 \mu \mathrm{g} / \mathrm{kg}$, however no residues were observed in muscles.

Deng et al., 2010 reported that long term exposure of Tilapia fish with different levels of AFB1 (19, 85, 245, 638, 793 and 1641 $\mu \mathrm{g} / \mathrm{kg}$ ) for 20 weeks, resulted the aflatoxicosis in a dose- and duration-dependent manner, 
also aflatoxin residues detected only in liver but not in edible flesh.

A residue of $11 \mu \mathrm{g} / \mathrm{kg}$ in liver from 40 chickens having been fed $50 \mu \mathrm{g}$ of ochratoxin per kg of feeding stuffs (Micco et al., 1987) also points in the same direction. A result of these estimates which is worth emphasizing is that the ochratoxin concentration in blood is clearly lower than that found in pigs. The highest levels were found in liver and kidney. Meat/muscle had relatively low levels.

Iqbal et al., 2014 from Pakistan, using reverse phase High Performance Liquid Chromatography (HPLC) with fluorescence detention, documented that $35 \%$ of chicken meat samples were positive for aflatoxins, with the maximum level of AFB1 and total aflatoxins found in the livers $2.98 \pm 0.76$ and $3.23 \pm 0.82 \mu \mathrm{g} / \mathrm{kg}$, respectively. El-Desouky et al., 2014 from Egypt, using immunoaffinity column with HPLC, reported the presence of AFB1 in 45,32 , and $25 \%$ of 60 chicken livers, gizzards, and hearts in their study samples, with an overall maximum level of $2.24 \mu \mathrm{g} / \mathrm{kg}$. Most of these previous findings are in complete agreement with the findings of the present study, although with different tissues and species

Our data are in the same line with Hassanin et al., 2016. They found that chicken burger (1.63 ppb), followed by chicken nuggets (1.04 $\mathrm{ppb})$, luncheon (0.98 ppb) and frankfurter (0.82 ppb), chicken thigh (0.68 ppb), pannet (0.43ppb) and finally chicken wings (0.29 $\mathrm{ppb}$ ). While the incidence is so lower than that reported in Egypt by Nahed et al., 2016 who reported that incidence of ochratoxin in chicken burger and luncheon was $70 \%$ and $80 \%$, respectively. The residue of ochratoxin was very low in their study, where OTA residues were 0.277 and $0.243 \mathrm{ppb}$ in chicken burger and luncheon, respectively. This could be explained by the fact that in our work we used HPLC-FLD which consider highly precise and accurate technique for determination of mycotoxins residues.

Our results are disagree with Hanif et al., 2012 who found that The highest OTA levels were detected in serum > kidneys $>$ liver of OTA treated groups of broilers after fed with two levels (500 and $1000 \mathrm{ppb}$ ) of ochratoxin A (OTA) and Tissue distribution in pigs, rats, chickens and goats generally follows the order kidney $>$ liver $>$ muscle $>$ fat (Harwig et $a l ., 1983)$, or in some recent studies kidney > muscle > liver > fat (Mortensen et al., 1983; Madsen et al., 1982), and completely disagreed with those achieved by Abo ElYazeed et al., 2015 who detected that the residual concentrations were higher in breast than in liver.

Mycotoxins residues in different chicken products after exposure to gamma irradiation:

In all analyzed samples, there are a positive correlation between the increase of gamma irradiation dose applied to the samples and the level of reduction of total mycotoxins present in these samples, however, the maximum reduction percentage of mycotoxins were achieved at $10 \mathrm{kGy}$; it reaches $37.88 \%$ for total mycotoxins, $27.22 \%$ for Afla B1, 40.12 $\%$ for Afla B2, $63.04 \%$ for Afla G1, $90.24 \%$ for Afla G2 and $73.83 \%$ for OTA. These results agree with Ghanem et al., 2008 who found that the dose of $10 \mathrm{kGy}$ percentages of AFB1 degradation reached highest values at 58.6, 68.8, 84.6, 81.1 and $87.8 \%$ for peanuts, 
peeled pistachios, unpeeled pistachios, corn and rice samples, respectively. \%. Their results indicate the possibility of using gamma irradiation as a means of degradation of AFB1 in food and feed crops to levels lower than the maximum allowed levels. While Vita et al., 2013investigated the effect of gamma irradiation dosages, ranging from 0 to $15 \mathrm{kGy}$ and the reduction of mycotoxins concentration in almond samples. The maximum reduction was found at $15 \mathrm{kGy}$ and it was $19.25 \%, 10.99 \%, 21.11 \%, 16.62 \%$, and $23.9 \%$ for AFB1, AFB2, AFG1, AFG2 and OTA respectively. Results showed that gamma radiations even at $15 \mathrm{kGy}$, were not effective in completely destroying aflatoxins and ochratoxin A.

Some researchers reported a significant reduction and in many cases the complete elimination of mycotoxins in various foods; Jalili, et al., 2010 who studied Gamma ray was applied to reduce mycotoxins, i.e. ochratoxin A (OTA) and aflatoxins B1, B2, G1 and G2 (AFB1, AFB2, AFG1 and AFG2) in black pepper. The maximum reduction was found at $60 \mathrm{kGy}$ which was $52 \%, 43 \%, 24 \%$, $40 \%$ and $36 \%$ for OTA, AFB1, AFB2, AFG1 and AFG2, respectively. Results showed the gamma rays even at $60 \mathrm{kGy}$ were not effective in completely destroying of ochratoxin and aflatoxins. These results were in agreement with the results obtained by Prado et al., 2003 who found that even at a dose of $30 \mathrm{kGy}$ in peanuts, the percentage of reduction achieved was about $61 \%$ and the destruction rate was nearly stable after the dose of $15 \mathrm{kGy}$. Also, the results were in agreement with Farage et al., 1995 who found that an $83 \%$ reduction of aflatoxin after a 20 -
kGy dose of $\gamma$-irradiation of yellow corn and peanuts was achieved. On the contrary, Aziz and Youssef, 2002 found that the dose of 20 kGy was sufficient to destroy completely AFB1 in peanuts, yellow corn, and cottonseed meal.

Herzallah et al., 2008 mentioned that the degradation rate increased with increased irradiation dose. For example, the concentrations of the total aflatoxin were 860 and $630 \mu \mathrm{g} / \mathrm{kg}$ after irradiation doses of 5 and $25 \mathrm{kGy}$, respectively, compared with the control treatment of $965 \mu \mathrm{g} / \mathrm{kg}$. The percentages of the reduction of aflatoxins achieved were 40.1 and $42.7 \%$ after a dose of irradiation of $25 \mathrm{kGy}$ in $\mathrm{T} 3$ for the total and B1 aflatoxins, respectively

Jalili et al., 2012 investigated the efficacy of gamma radiation $\left({ }^{60} \mathrm{Co}\right)$ for decontaminating ochratoxin A (OTA) and aflatoxins B1 (AFB1), B2 (AFB2), G1 (AFG1) and G2 (AFG2) residues in artificially contaminated black and white pepper samples. Mycotoxin levels were determined by high-performance liquid chromatography (HPLC) after immunoaffinity column (IAC) chromatography. Both the gamma irradiation dose and moisture content showed significant effects $(P<0.05)$ on mycotoxin reduction. The maximum toxin reductions, found at $18 \%$ moisture content and $30 \mathrm{kGy}$, were $55.2 \%$, $50.6 \%, 39.2 \%, 47.7 \%$ and $42.9 \%$ for OTA, AFB1, AFB2, AFG1 and AFG2, respectively.)

Our results are in complete disagreement with findings obtained by Hooshm and Klopenstein, 1995 and Feuell, 1966 found that different radiation doses of $5,7.5,10$ or $20 \mathrm{kGy}$ did not significantly affect aflatoxin 
B1 when applied to spiked grain samples, and the residual toxins were measured using an enzyme linked immunosorbent assay (ELISA).

Expression of nor-1 gene of aflatoxins and ocrA gene of ochratoxinin polluted poultry products by a real time PCR (RT-PCR) technique:

A multiplex polymerase chain reaction (PCR) strategy was established for rapid identification of mycotoxigenic fungi (Sadhasivam et al., 2017).

The RT-PCR results obtained with genomic DNA as a template indicated that all tested aflatoxigenic isolates expressed nor-1 gene with significant expression levels in chicken products. Positive correlation was noted between mean expression level of nor-1 and the amount of Aflatoxins production by isolates.

The observed differences in aflatoxins producing ability could be explained by differences in expression of aflatoxins biosynthetic and regulatory genes between toxigenic isolates from chicken products due to distinction in environmental circumstances. Transcriptional expression of the key aflatoxins biosynthetic gene nor-1 gene which encoding an enzyme catalyze the conversion of the first stable aflatoxins biosynthesis intermediate norsolorininc acid to averatin. Nor-1 gene was investigated by Real time PCR as the nor-1 gene expressed in different levels. These result was in agreement with that obtained by Yousefi et al., 2009; Iheanacho, 2012 and Passon et al., 2010 who found that A.oryzea and A.niger expressed the nor-1 gene and with Mayer et al., 2003 who found that A.Oryzea expressed expressed the nor-1 gene, and disagree with Mahmoud, 2015 found that A.flavus expressed (nor-1) and other strains expressed a regulatory alfR. Moreover, Cruz and Buttner, 2008 found that A.flavus have alfR gene and expressed it with different levels. While, Schermet al., 2005 stated that there are some other genes, alfR and alfQ present in toxigenic strains of A.flavus and A.parsiticus controlled in aflatoxin biosynthesis

\section{REFERENCES}

Abarca, M.L.; Accensi, F.; Bragulat, M.R. and Cabanes, F.J. (2001): Current importance of ochratoxin A-producing Aspergillus spp. Journal of Food Protection, 64: 903-906.

Abd-Elghany, S.M and Sallamm, K.I. (2015): Rapid determination of total aflatoxins and ochratoxins $\mathrm{A}$ in meat products by immuno-affinity fluorimetry. Food Chem; 179: 253- 256.

Abdel-Rahman, G.N.; Sultan, Y.Y.; Salem, S.H and Amer, M.M. (2019): Identify the natural levels of mycotoxins in Egyptian roasted peanuts and the destructive effect of gamma radiation. The Journal of Microbiology, Biotechnology and Food Sciences, 8 (5): 1174.

Abo El-Yazeed, H.; Hanafy, M.H.; Soliman, $\mathrm{R}$ and Refai, M., (2015): Trials for Reducing Aflatoxin B1 residues in chicken meat and eggs using a newly developed Aflatoxin B1 vaccine. International Journal of Research Studies in Biosciences (IJRSB) 3: 6-14. 
Arulmozhi, A., Koshy. V., Ismail, P.K., Peethambaran, P.A. and Ramachandran, K.M. (2002): Aflatoxin residues in tissues of broiler chicken. Indian Vet. J., 79: 901-903.

Aziz, N.G.; Moussa, A.A and Ferial M.E., (2004): Reduction of fungi and mycotoxins formation in seeds by gamma-radiation. Journal of Food Safety 24: 109-127.

Aziz, N.H and Youssef, B.M., (2002): Inactivation of naturally occurring of mycotoxins in some Egyptian foods and agricultural commodities by $\gamma-$ irradiation. Egypt. J. Food Sci. 30:167177.

Bennett, J.W and Klich, M., (2003): Mycotoxins. Clin. Microbiol. Rev.; 16: 497-516.

Bintvihok, A and Davitiyananda, D. (2002): Aflatoxins and their metabolites residues in chicken tissues from 5 parts (10 provinces) of Thailand. Thail. J. Health Res.; 16: 37-50.

Bintvihok, A.; Treebonmuang, S.; Srisakwattana, K.; Nuanchun, W.; Patthanachai, K and Usawang, S., (2016): A rapid and sensitive detection of aflatoxin-producing fungus using an optimized polymerase chain reaction (PCR). Toxicol. Res., 32: 81-87.

Biro, K.; Solti,L.; Barna - Vetro, I.; Bago,G.; Glavits, R.; Szabo, E and FinkGremmela, J. (2002): Tissue distribution of ochratoxin $\mathrm{A}$ as determined by HPLC and ELISA and histopathological effects in chickens. Avian Pathol., 31: 141-148.

Blesa, J.; Soriano, J.M.; Molt, J.C.; Maryer, R.; Ma, J. and Nes, J., (2003): Mycotoxin detection. Chromatogr. A, 1011: 49-54.

Braghini, R.; Rocha, L.O.; Pozzi, C.R.; Frizzarin, A and Reis, T.A. (2015): Effect of Gamma Radiation on Growth and Mycotoxins Production of Alternaria alternata. Fungal Genom Biol., 5: 128.

Brera, C.; Debegnach, F.; De Santis, B.; Pannunzi, E.; Berdini, C and Prantera, E. (2011): Simultaneous determination of aflatoxins and ochratoxin A in baby foods and paprika by HPLC with fluorescence detection. Talanta, 83(5): $1442-1446$.

Calado, T.; Fernández-Cruz, M.L.; CaboVerde, S.; Venâncio, A and Abrunhosa, L. (2018): Gamma irradiation effects on Ochratoxin-A: Degradation, cytotoxicity and application in food. Food Chem., 240: 463- 471.

Castella, G.; Larsen, T.O.; Cabanes, F.J.; Schmidt, H.; Alboresi, A.; Niessen, L.; Farber, P and Geisen, R. (2002): Molecular characterization of ochratoxin A producing strains of the genus Penicillium. Systematic and Applied Microbiology, 25:74-83.

Cruz, P. and Buttner, M.P. (2008): Development and evaluation of a real- 
time quantitative PCR assay for Aspergillus flavus. Mycologia, 100: 683-690.

Dance, Z.; Popa, M.; Morar, M.V.; Macri, A.; Mihalca, I and Buda, I., (2003): A survey of the occurrence of fungi with mycotoxic potential in grain of transilvania, 25 Mycotoxin-workshop, Giessen. Rev. Med. Vet. 13.

Darwish, W.S.; ELBayomi, R.M.; Abd ELoaty; A.M and Gad, T.M., (2016): Mould contamination and aflatoxin residues in frozen chicken meat cuts and giblets. Japanese Journal of Veterinary Research, 46: 167-171.

Darwish, W.S.; Ikenaka, Y.; Nakayama, S.M.M and Ishizuka, M. (2014): An overview on mycotoxin contamination of foods in Africa. The Journal of Verterinary Medical Science, 76(6): 789- 797.

Deng, S.X.; Tian, L.X.; Liu, F.J.; Jin, S.J.; Liang, G.Y.; Yang, H.J.; Du, Z.Y and Liu, Y.J. (2010): Toxic effects and residue of aflatoxin B1 in tilapia (Oreochromis niloticus O. aureus) during long-term dietary exposure. Aquaculture, 307: 233- 240.

Dhanya, R.; Mishra, B.B.; Khaleel, K.M and Cheruth, A.J., (2009): Shelf life extension of fresh turmeric (Curcumal onga L.) using gamma radiation. Rad. Phys. Chem., 78: 791-795.

Di Stefano, V.; Pitonzo, R and Avellone, G. (2014): Effect of gamma irradiation on aflatoxins and ochratoxin A reduction in almond samples. J Food Res., 3:113-118.

Diao, E.J.; Shen, X.Z.; Zhang, Z.; Ji, N.; Ma, W.W.; Dong, H.Z. Safety evaluation of aflatoxin B1 in peanut oil after ultraviolet irradiation detoxification in a photodegradation reactor. Int. J. Food Sci. Tech. 2015, 50, 41-47.

Domijan, A.M.; Marjanović Čermak, A.M.; Vulić, A.; Tartaro Bujak I.; Pavičić, I.; Pleadin, J.; Markov, K and Mihaljević, B. (2019): Cytotoxicity of gamma irradiated aflatoxin B1 and ochratoxin A. J Environ Sci Health B.; 54(3): 155162.

Domijan, A.M.; Pleadin, J.; Mihaljević, B.; Vahčić, N.; Frece, J and Markov, K. (2015): Reduction of ochratoxin A in dry-cured meat products using gammairradiation. Food Addit Contam., 32: 1185- 1191.

Dorner, J.W. (2004): Biological control of aflatoxin contamination 0T3. OTof crops. J Toxicol- Toxin Rev., 23: 425450.

Dragan, R.M.; Milijan, J.; Vesna, F.M.; Tatjana, R.; Milan, M.P and Dubravka, Ž.V., (2011): Residue of ochratoxin A in chicken tissues-risk assessment. Arch Oncol, vol.19 (1 -2): 23-27.

El-Desouky, T.A.; Mohamed, S.R.; AbouArab, A.A.K and Salim, A.B. (2014): Occurrence of aflatoxin B1 and M1 in some Egyptian chicken organs and their affected by ozonated water. Open Sci. J. Mod. Phys., 1: 24-30. 
Fan, Y.; Zhao, L.H.; Ma, Q.G.; Li, X.Y.; Shi, H.Q.; Zhou, T.; Zhang, J.Y and Ji, C. (2013): Effects of Bacillus subtilis ANSB060 on growth performance, meat quality and aflatoxin residues in broilers fed moldy peanut meal naturally contaminated with aflatoxins. Food Chem. Toxicol. 59: 748- 753.

Farage, R.S.; Rashed, M.M.; Hussein, A.A and Abo-Hagar, A., 1995: Effect of $\gamma$ radiation on the infected yellow corn and peanuts by Aspergillus flavus. Chem. Mikrobiol. Technol. Lebensm. 17: 93-98.

Fente C.A.; Jaimez, J.O.; Vazquez, B.I.; Franco, C.M and Cepeda, C.M., (2001): New Additive for Culture Media for Rapid Identification of Aflatoxin-Producing Aspergillus Strains. Appl. Environ. Microbiol., 67(10): 4858- 4862.

Feuell, A.J., (1966): Aflatoxin in groundnuts. Problems of detoxification. Trop. Sci., 8: 61- 70 .

Frisvad, J.C. and Samson, R.A., (2000): Neopetromyces gen. nov. and an overview of teleomorphs of Aspergillus subgenus Circumdati. Studies in Mycology, 45: 201- 207.

Ghanem, I.; Orfi; $M$ and Shamma, M., (2008): Effect of gamma radiation on the inactivation of aflatoxin B1 in food and feed crops. Brazilian Journal of Microbiology. 39: 787- 791.
Gupta, S.C., (2001): Irradiation as an alternative treatment to methyl bromide for insect control. FAO/IAEA/WHO, Vienna, Austria.

Harwig, J.; Kuiper, G.T and Scott, P.M. (1983): Microbial food toxicants: Ochratoxin. In: Handbook of food borne diseases of biological origin, CRC Press, Boca Raton, FL.M. Rechcigl, Edn., pp 193-238.

Hasanen, F.S.; Mousa, M.M.; Mahomud, A.H.; Wafaa, M.H and Fatma, H.A. (2016): Aflatoxins residues in chicken and turkey tissues. Benha Vet. Med. J., 31(2): 130-135.

Hassan, F.F. (2018): Detection of Aflatoxin B1 in Some Canned Foods and Reduction of Toxin by Ultraviolet Radiation. Iraqi Journal of Science, [S.1.]: 2343- 2349.

Hassan, M.N.; El-Sayed, A.S.A and Nada, H.M.S., (2015): Detection of aflatoxins by HPLC and the expression of biosynthetic nor-1 gene of aflatoxin and ocrA gene of ochratoxin. Benha Veterinary Medical Journal, VOL. 29, NO. 2:1 10.

Hassanin, F.S.; Abd- Allah, T.Z and El-Shater, M., (2016): Ochratoxin in some Poultry Meat Products. Benha Journal of Applied Sciences, Vol. (1) Issue (2).

Herzallah S.; Al-Ameiri N.; Al-Dmoor H.; Masoud S. and Shawabkeh K., (2014): Meat and organs quality of broiler 
chickens fed diet contaminated with B1 aflatoxin. Glob. Vet., 12: 376-380.

Herzallah, S.; Alshawabkeh, 1.K and ALFataftah, A., (2008): Aflatoxin Decontamination of Artificially Contaminated Feeds by Sunlight, $\gamma$ Radiation, and Microwave Heating. J. Appl. Poult. Res. 17: 515-521.

Herzallah, S.; Alshawabkeh, $\mathrm{K}$ and ALFataftah, A. (2008): Aflatoxin Decontamination of Artificially Contaminated Feeds by Sunlight, gamma Radiation and Microwave Heating. J. Applied Poultry Res.; 17(4): 515-21.

Herzallah, S.M. (2009): Determination of aflatoxins in eggs, milk, meat and meat products using HPLC fluorescent and UV detectors. Food Chem., 114: 11411146.

Hussain, Z.; Khan, M.Z and Saleemi, M.K. (2016): Clinicopathological effects of prolonged intoxication of aflatoxin B1 in broiler chicken. Pak Vet J., 36: 477481.

Hussain, Z.; Khan, M.Z.; Khan, A.; Javed, I.; Saleemi, M.K and Mahmood, S. (2010): Residues of aflatoxin B1 in broiler meat: effect of age and dietary aflatoxin B1 levels. Food Chem. Toxicol., 48: 3304- 3307.

Iacumin, L.; Chiesa, L.; Boscolo, D.; Manzano, M.; Cantoni, C.; Orlic S and Comi, G. (2009):.Moulds and ochratoxin A on surfaces of artisanal and industrial dry sausages. Food Microbiol., 26: 65-70.

Iacumin, L.; Manzano, M.; Panseri, S.; Chiesa, L and Comi, G. (2016): A new cause of spoilage in goose sausages. Food Microbiol., 58: 56-62.

IARC, (1993): Aflatoxins. In Some Naturally Occurring Substances: Food Items and Constituents, Heterocyclic Aromatic Amines, and Mycotoxins. IARC Monographs on the Evaluation of Carcinogenic Risk of Chemicals to Humans, vol. 56. Lyon, France: International Agency for Research on Cancer. pp. 245-395.

IARC, (2002): Aflatoxins. In Traditional Herbal Medicines, Some Mycotoxins, Naphthalene and Styrene. IARC Monographs on the Evaluation of Carcinogenic Risks to Humans, vol. 82. Lyon, France: International Agency for Research on Cancer. pp. 171-366.

$\mathrm{ICH}$, (2005): International conference on harmonization of technical requirements for registration of pharmaceuticals, validation of analytical procedures; methodology, harmonized tripartite guideline. ICH, Geneva.

Iheanacho, H., (2012): The expression of the norlgene of Aspergillus spp. And Aflatoxin production in compound feed from South Africa in relation to animal health disorders faculty of Johansburk PHD Thesis. 
Iqbal, S.Z.; Nisar, S.; Asi, M.R and Jinap, S. (2014): Natural incidence of aflatoxins, ochratoxin $\mathrm{A}$ and zéaralénone in chicken meat and eggs. Food Control, 43: 98- 103 .

Iqbal, S.Z.; Rabbani, T.; Asi, M.R and Jinap, S. (2014): Assessment of aflatoxins, ochratoxin A and zearalenone in breakfast cereals. Food Chemistry, 157c: 257- 262.

Ismail, M.A and Zaky, Z.M. (1999): Evaluation of the mycological status of luncheon meat with special reference to aflatoxigenic moulds and aflatoxin residues. Mycopathologia, 146: 147154.

Ivica-Vujcic, S.; Masic, M.; Medic, M.; Timotijevic, $\mathrm{M}$ and Dramicanin, $\mathrm{D}$. (2017): Effect of gamma radiation on the inactivation of aflatoxin in hemp flour. Eco-Ist'17, Ecological Truth, Hotel "BREZA", Vrnjačka Banja.

Jaimez, J.; Fente, C.A.; Vazquez, B.I.; Franco, C.M.; Cepeda, A and Mahuzier, G., (2000): Application of the assay of aflatoxins by liquid chromatography with fluorescence detection in food analysis. J. Chromatogr. A, 882: 1-10.

Jalili, M.; Jinap, S and Noranizan, M.A, (2010): Effect of gamma radiation on reduction of mycotoxins in black pepper. Food Control, 21: 1388- 1393.

Jalili, M.; Jinap, S and Noranizan, M.A., (2012): Aflatoxins and ochratoxin a reduction in black and white pepper by gamma radiation. Rad. Phys. Chem., 81: 1786- 1788 .

Kalcher, T.C.; Vrta, C.; Pestev, S.E.K. and Vengu, S.T. (2007): Validation of the procedure for the determination of aflatoxin B1 in animal liver using immune-affinity columns and liquid chromatography with post column derivatization and fluorescence detection. Food Control 18: 333- 337.

Kaynarca, H.D.; Hecer, C and Ulusoy, B. (2019): Mycotoxin Hazard in Meat and Meat Products. Atatürk Üniversitesi Vet. Bil. Derg.;14(1): 90- 97.

Khan, M.; Hameed, M.; Hussain, T.; Khan, A.; Javed, I.; Ahmad, I.; Hussain, A.; Saleemi, M and Islam, N. (2013): Aflatoxin residues in tissues of healthy and sick broiler birds at market age in Pakistan: A one-year study. Pak Vet J., 33: 423-427.

Kuiper-Goodman, T and Scott, P.M., (1989):

Risk assessment of the mycotoxin ochratoxin A. Biomed. Environ. Sci., 2: 239- 248.

Lacumin, L.; Chiesa, L.; Boscolo, D.; Manzano, M.; Cantoni, C.; Orlic, S and Comi, G., (2009): Moulds and ochratoxin A on surfaces of artisanal and industrial dry sausages. Food Microbiol 26: 65- 70.

Larsen, T.O.; Svendson, A. and Smedsgaard, J., (2001): Biochemical characterization of ochratoxin-A producing strains of Penicillium. 
Applied and Environmental Microbiology, 67: 3630-3635.

Lobeau, M., (2005): Development of a new clean-up tandem assay column for the detection of ochratoxin $\mathrm{A}$ in roasted coffee Analytica Chimica Acta, vol.538: pp.57- 61 .

Madsen, A., Mortensen, H.P. and Hald, B. (1982): Feeding experiments with ochratoxin-A contaminated barley for bacon pigs and influence on pig performance and residues. Acta Agric. Scand., 32: 225-239.

Mahmoud, M.A. (2015): Detection of Aspergillus flavus in Stored Peanuts Using Real-Time PCR and the Expression of Aflatoxin Genes in toxigenic and toxigenic A. flavus Isolates. Food borne pathogen and disease Mary Ann Liebert, Inc. 1: 1-6.

Markov, K.; Pleadin, J.; Bevardi, M.; Vahcic, N.; Sokolic-Mihalak, D and Frece, J. (2013): Natural occurrence of aflatoxin B1, ochratoxin A and citrinin in Croatian fermented meat products. Food Control; 34: 312- 317.

Martín-Sánchez, A.M.; Chaves-López, C.; Sendra, E.; Sayas, E.; Fenández-López, J. and Pérez-Álvarez, J.A., (2011): Lipolysis, proteolysisand sensory characteristics of a Spanish fermented dry-cured meat product with oregano essential oil used as surface moldinhibitor. Meat Sci. 89: 35- 44.

Mayer, Z.; Bagnara, A.; Färber, P and Geisen, R. (2003): Quantification of the copy number of nor-1, a gene of the aflatoxins biosynthetic pathway by real-time PCR, and its correlation to the CFU of Aspergillus flavus in foods. International Journal of Food Microbiology, 82: 143-151.

Mehrez, A.; Maatouk, I.; Romero-González, R.; Amara, A.B.; Kraiem, M.; Frenich, A.G and Landoulsi, A. (2016): Assessment of ochratoxin A stability following gamma irradiation: experimental approaches for feed detoxification perspectives. World Mycotoxin J., 9: 289- 298.

Meri, K.; Marika, J. and Aldo, R. (2005): The effect of substrate on mycotoxin production of selected Penicillium strains. Int. J. Food Microbiol., 99: 207- 214.

Micco, C.; Brera, C.; Miraglia, M and Onori, R. (1987): HPLC determination of the total content of aflatoxins in naturally contaminated eggs in free and conjugated forms. Food Addit Contam., 4: 407-414.

Milićević, D.R.; Jovanović, M.; MatekaloSverak, V.F.; Radičević, T.; Petrović, M.M and Vuković, D.Z. (2011) Residue of ochratoxin $A$ in chicken tissues-risk assessment. Archive of Oncology; 19 (1-2): 23-27.

Miliță, N.M.; Mihăescu, G and Chifiriuc, C. (2010): Aflatoxins health risk factors. Bacteriol Virusol Parazitol Epidemiol 55: 19- 24. 
Mizakova, A.; Pipova, $\mathrm{M}$ and Turek, $\mathrm{P}$. (2002): The occurrence of moulds in fermented raw meat products. Czech J. Food Sci., 3: 89- 94.

Monaci, L. and Palmisano, F. (2004): Determination of OTA in foods: State of the art and analytical challenges. Analytical and Bio analytical Chemistry, vol.378: pp.96- 103.

Morshdy, A.E.M.A.; Hussien, M.A.M.; ElAbbasy, M.T and Elzwahery, R.R.M. (2015): Aflatoxins Residues in Some Meat Products. $2^{\text {nd }}$ Conference of Food Safety, Suez Canal University, Faculty of Veterinary Medicine, I: 90-95.

Mortensen, H.P.; Hald, B and Madsen, A. (1983): Feeding experiments with ochratoxin-A contaminated barley for bacon pigs and ochratoxin A in pig blood. Acta Agric. Scand., 33: 235-239.

Nahed, M.; Enas, M.; Manal, E and El-Latef, R.M. (2016): Estimation of some mycotoxin residues in meat and poultry products. Animal Health Res. J., vol.4 (2): $1-12$.

Niessen, L. (2008): PCR-based diagnosis and quantification of mycotoxin-producing fungi. Advances in Food and Nutrition Research, 54: 81-138.

Okorski, A.; Polak-Sliwinska, M.; Karpiesiuk, K.; Pszczolkowska, A and Kozera, W. (2017): Real time PCR: A good tool to estimate mycotoxin contamination in pig diets. World Mycotoxin J., 10: 219222.
Orina, A.S.; Olga P.G and Tatiana, Y.G, (2018): Adaptation of the quantitative PCR method for the detection of the main representatives of cereal grain mycobiota. Microbiology Independent Research Journal, 1(5): 78- 83.

Passone, P.M.A.; Rosso, L.C.; Ciancio, A. and Etch, M. (2010): Detection and quantification of Aspergillus section Flavi spp. in stored peanuts by realtime PCR of nor-1 gene, and effects of storage conditions on aflatoxin production. International Journal of Food Microbiology, 138: 276-281.

Patel, U.D.; Govindarajan, P and Dave, P.J. (1989): Inactivation of aflatoxin Bl by using the synergistic effect of hydrogen peroxide and gamma radiation. Appl. Environ. Microbial., 55: 465-467.

Patil, H.; Shah, N.G.; Hajare, S.N.; Gautam, S and kumar, G. (2019): Combination of microwave and gamma irradiation for reduction of aflatoxin B1 and microbiological contamination in peanuts (Arachis hypogaea L.). World Mycotoxin Journal: 12 (3): 269 - 280.

Perši, N.; Pleadin, J.; Kovačević, D.; Scortichini, G and Milone, S. (2014): Ochratoxin-A in raw materials and cooked meat products made from OTA-treated pigs. Meat Sci.; 96: 203210.

Pietruszka, K.; Piątkowska, M and Jedziniak, P. (2017): Occurrence of ochratoxin A in animal tissues and feeds in Poland in 2014-2016. J. Vet. Res., 61. 
Prado, G.; De Carvalho, E.P., Oliveira, M.S.; Cruz Madeira, J.G.; Morais, V.D.; Correa, R.F.; Cardoso, V. N.; Soares, T.V.; Moreira da Silva, J.F and Pereira, R.C. (2003): Effect of $\gamma$ irradiation on the inactivation of aflatoxin B1 and fungal flora in peanut. Braz. J. Microbiol. 34: 138- 140.

Priyanka, S.R.; Ramana, M.V.; Shilpa, P.; Balakrishna, K.; Murali, H.S and Batra, H.V. (2013): Development and evaluation of a multiplex PCR assay for simultaneous detection of major mycotoxigenic fungi from cereals. $\mathrm{J}$ Food Sci Technol., 2: 577-586.

Razzaghi-Abyaneh, M.; Shams-Ghahfarokhi, M.; Allameh, A.; Kazeroon-Shiri, A.; Vahl, S.M. and Jorgensen, K. (2006): Determination of Aflatoxins in Food Using LC/MS/MS. $Z$ Lebensm Unters Forsch A., 206: 243- 245.

Resanović, R. (2000): Ispitivanje zaštitnog dejstva modifikovanog klinoptilolita na živinu izloženu deistvu aflatoksina. Doktorska disertacija, Fakultet veterinarske medicine Univerzitet $\mathrm{u}$ Beogradu, Beograd. (Sr).

Resanović, R.M.; Nešić,K.D.; Nesić, VD, Palić, T.D and Jaćević, V.M. (2009): Mycotoxins in poultry production. Zbornik Matice Srpske za prirodne Nauke., 116: 7-14.

Ribeiro, J.; Cavaglieri, L.; Vital, H.; Cristofolini, A.; Merkis, C.; Astoreca, A.; Orlando, J.; Caru, M.; Dalcero, A. and Rosa, C.A. (2011): Effect of gamma radiation on Aspergillus flavus and Aspergillus ochraceus ultrastructure and mycotoxin production. Rad. Physics Chemistry, 80: 658- 663 .

Rodrigues, P.; Ven^ancio, A.; Kozakiewicz, Z and Lima, N. (2009): A polyphasic approach to the identification of aflatoxigenic and non-aflatoxigenic strains of Aspergillus section Flavi isolated from Portuguese almonds. International Journal of Food Microbiology, 129(2): 187- 193.

Rodriguez, A.; Rodriguez, M.; Andrade, M.J and Cordoba, J.J. (2012): Development of a multiplex real-time PCR to quantify aflatoxin, ochratoxin $\mathrm{A}$ and patulin producing molds in foods. International Journal of Food Microbiology 155: 10-18.

Rodríguez-Amaya, D.B and Sabino, M. (2002): Mycotoxin research in Brazil: The last decade in review. Braz. J. Microbiol.; 33: 1-11.

Rogovschi, V.D.; Aquino, S.; Zorzete, P.; Reis, T.A.; Corrêa, B and Villavicencio, A.L.C.H. (2007): Use of gamma radiation and electron beam treatment on decontamination of coconut agar medium used in the production of aflatoxins. AccApp'07: 1026- 1027.

Saccomori F.; Wigmann, E.F.; Bernardi, A.O.; Alcano-Gonzalez, M.J and Copetti, M.V. (2015): Influence of storage temperature on growth of Penicillium 
polonicum and Penicillium glabrum and potential for deterioration of frozen chicken nuggets. Int J Food Microbiol., 200: 1-4.

Sadhasivam, S.; Britzi, M.; Zakin, V.; Kostyukovsky, M.; Trostanetsky, A.; Quinn, E and Sionov, E. (2017): Rapid Detection and Identification of Mycotoxigenic Fungi and Mycotoxins in Stored Wheat Grain. Toxins, 9: 302.

Saeed, A.; Afzal, S.; Hussien, M.W.; Bokhari, S.Y.A.; Shahzad, M.S.; Qayyoum, A and Raza, M.H. (2003): Effect of aflatoxin B1 on different body tissues of Gallus Domesticus. Journal of animal and veterinary Advances, 2: 7678.

Samarajeewa, U.; Sen, A.; Cohen, M and Wei, C. (1990): Detoxification of Aflatoxins in Foods and Feeds by Physical and Chemical Methods. Journal of Food Protection , 489-501.

Sambrook, J.; Fritsch, E.F and Maniatis, T. (1989): Molecular Cloning. A Laboratory Manual. Cold Spring: Laboratory Press.5: 1- 4.

Scherm, B.; Palomba, M.; Serra, D.; Marcello, A and Migheli, Q. (2005): Detection of transcripts of the aflatoxin genes aflD, aflO, and aflP by reverse transcription- polymerase chain reaction allows differentiation of aflatoxin-producing and non-producing isolates of Aspergillus flavus and Aspergillus parasiticus. Int. J. Food Microbiol., 98: 201- 210.
Serra, M.S.; Pulles, M.B.; Mayanquer, F.T.; Vallejo, M.C.; Rosero, M.I.; Ortega, J.M and Naranjo, L.N. (2018): Evaluation of the Use of Gamma Radiation for Reduction of Aflatoxin B1 in Corn (Zea mays) Used in the Production of Feed for Broiler Chickens. Journal of Agricultural Chemistry and Environment, 7: 21-33.

Shaltout, F.A.; Amin, R.A.; Nassif, M.Z and Abd-Elwahab, S.A. (2014): Detection of aflatoxins in some meat products .Benha Veterinary Medical Journal, 27(2): 368-374.

Sineque, A.R.; Macuamule, C.L and DosAnjos, F.R. (): Aflatoxin b1 contamination in chicken livers and gizzards from industrial and small abattoirs, measured by ELISA technique in maputo, mozambique. Int. J. Environ. Res., 14, 951.

Soliman, M.M.H.; Ata, N.S.; ElShafei, H.M and Kandil, M.M.A. (2019): Prevalence of toxigenic Aspergillus flavus in meat and meat products. Bioscience research, 16(1): 822-829.

Somashekar, D.; Rati, E.R. and Chandrashekar, A. (2004): PCRrestriction fragment length analysis of aflR gene for differentiation and detection of Aspergillus flavus and Aspergillus parasiticus in maize. Int. J. Food Microbiol., 93: 101-107.

Talebi, E.; Khademi, M. and Rastad, A. (2011): An Over Review on Effect of 
Aflatoxin in Animal Husbandry. Asian

J. Exp. Biol. Sci. 2: 754- 757.

United States pharmacopeia convention (USP), (2017): United States pharmacopeia, $40^{\text {th }}$ edn. USP, physical tests/ (621) chromatography, Rockville: 508- 520 .

Vita, D.S.; Rosa, P and Giuseppe, A. (2014): Effect of Gamma Irradiation on Aflatoxins and Ochratoxin-A Reduction in Almond Samples. Journal of Food Research, 3(4), 113.

WHO, (2002): Evaluation of certain mycotoxins in food. Fifty-sixth report of the Joint FAO/WHO Expert Committee on Food Additives, WHO Technical Report Series 906, World Health Organization (WHO), Geneva, Switzerland.

Yang, J.; Bai, F.; Zhang, K.; Lv, X.; Bai, S.; Zhao, L.; Peng, X.; Ding, X.; Li , Y and Zhang, J. (2012): Effects of feeding corn naturally contaminated with AFB1 and AFB2 on performance and aflatoxin residues in broilers. Czech. J. Anim. Sci., 57(11): 506-515.

Yang, L.; Zhao, Z.; Wu, A.; Deng, Y and Zhou, Z. (2013): Determination of trichothecenes A (T-2 toxin, HT-2 toxin, and diacetoxyscirpenol) in the tissues of broilers using liquid chromatography coupled to tandem mass spectrometry. J. Chromatogr. B; 942-943:88-97.

Yousefi, S.; Dadgar, S.; Safara, M. and Zaini, F. (2009): Aflatoxin production by
Aspergillus flavus isolates from greentiger shrimps (Penaeus semisulcatus). Iranian journal of microbiology, 1 (4): 18-22.

Youssef, H and Klopenstein, C.F., (1995): Effects of gamma irradiation on mycotoxin disappearance and amino acid contents of corn, wheat, and soybeans with different moisture contents. Plant Foods Hum. Nutr., 47: 227- 238.

Youssef, M.B.; Mahrous, S.R and Aziz, N.H. (1999): Effect of gamma-irradiation on aflatoxin B1 production by Aspergillus flavus in ground beef stored at $5 \mathrm{C}$. Journal of Food Safety, 19: 231-239.

Yu, J.; Payne, G.A.; Campbell, B.C.; Guo, B.; Cleveland, T.E and Robens, J.F. (2008): Mycotoxin production and prevention of aflatoxin contamination in food and feed. Boca Raton: CRC Press.

Zahid, H.; Muhammad, Z.K.; Ahrar, K.; Ijaz, J.; Muhammad, K.S., Sultan, M. and Muhammad, R.A. (2010): Residues of aflatoxin B1 in broiler meat: Effect of age and dietary aflatoxin B1 levels. Food Chem. Toxicol., 48: 3304-3307.

Zohri, A.A.; Moharram, A.M and Refaie, R.R.S. (2014): Mycobiota contaminating beef burger and sausage with reference to their toxins and enzymes. J Basic Appl Mycol., 5: 61. 